\title{
EMPIRIJSKO ISTRAŽIVANJE STAVOVA KORISNIKA O SUPRIJEVOZU U REPUBLICI HRVATSKOJ
}

\author{
Dora Naletina \\ Dr. sc., docentica, Ekonomski fakultet, Trg J. F. Kennedy 6, 10000 Zagreb, Hrvatska; \\ e-mail:dvuletic@net.efzg.hr \\ Ivan Kovač \\ Dr. sc., izvanredni profesor, Ekonomski fakultet, Trg J. F. Kennedy 6, 10000 Zagreb, Hrvatska; \\ e-mail: ivan.kovac@efzg.hr
}

\section{Dora Palić}

Mag. oec.e-mail: dora.palic4@gmail.com

\begin{abstract}
SAŽETAK
Ubrojnim svjetskim gradovima brojstanovnika kontinuirano raste, a za iste to predstavlja velik problem obzirom da im infrastruktura nije bila dizajnirana da omogući kretanje tako velikog broja ljudi. Uslijed navedenog dolazi do zagušenja u prometu u urbanim područjima, zagađenja okoliša, rasta potrošnje neobnovljivih izvora energije, ali i porasta buke koju stvaraju vozila. Posljednjih godina se, kao moguće rješenje na sve veću potražnju za mobilnošću stanovništva, upravo javlja suprijevoz odnosno sustav dijeljenja automobila koji se temelji na načelu održivog razvoja. U proteklim desetljećima cestovna mreža se u većini država širila kao odgovor na sve veći broj automobila koje stanovnici posjeduju. Zbog porasta broja automobila uz gotove jednake parkirališne kapacitete kao u desetljećima ranije, većina osoba se sve češće susreće s problemom pronalaska parkirnih mjesta u urbanim središtima. Navedeno, ali i troškovi koje uz sebe veže posjedovanje osobnog automobila, utjecali su na značajan porast popularnost suprijevoza u svijetu. Svrha ovog rada je istražiti stavove korisnika o suprijevozu u Republici Hrvatskoj. Carsharing organizacije omogućuju korisnicima kratkoročnu uporabu vozila iz voznog parka, ali i utječu na smanjenje potrebe za posjedovanjem privatnog vozila. Rezultati provedenog primarnog istraživanja pokazali su kako iako je prisutan na hrvatskom tržištu, suprijevoz koristi manji broj ispitanika. Ispitanici koji se koriste uslugama suprijevoza kao razloge navode manje troškove, izbjegavanje problema s traženjem parkinga te davanje doprinosa zaštiti okoliša. Pozitivno je što najveći dio ispitanika koji još nisu koristili usluge suprijevoza navodi kako će koristi usluge istog u budućnosti.
\end{abstract}

Ključne riječi: suprijevoz, mobilnost, gradski promet 


\section{UVOD}

Sve veća potreba za putovanjem odnosno za prijevozom do određenog odredišta uz značajan porast broja stanovnika u svijetu, dovodi do brojnih negativnih posljedica u urbanim sredinama kao što su zagađenje okoliša, prometna zagušenja koja su uzrokovana prevelikom koncentracijom vozila te potrošnjom neobnovljivih izvora energije. Suprijevoz pozitivno utječu ne samo na korisnike usluga sustava dijeljenja automobila već i na cjelokupno društvo, gospodarstvo i okoliš (Fournier et al., 2015). Većina vozila koja se koriste u flotama za dijeljenje automobila su super mini ili mali obiteljski automobili. Upotrebom ekonomičnih malih automobila pružatelji usluga suprijevoza podržavaju korisničke naknade koje se ocjenjuju prema veličini vozila. Tako korisnik može donijeti svjesnu odluku o uštedi goriva i smanjenju emisije $\mathrm{CO}_{2}$ kroz odabir vozila. Vozila za dijeljenje automobila u pravilu su novija od većine osobnih vozila, što znači da su poboljšanja u tehnologiji motora, učinkovitosti goriva i razine emisije ispunjena brže u vozilima za dijeljenje automobila nego u osobnim vozilima. Stoga svaki kilometar prijeđen automobilom koji se koristi za suprijevoz, rezultira s manje štetnih tvari u zraku i manje štetnih tvari za zdravlje kao i manjom potrošnjom goriva (Loose, 2010). Sudionici dijeljenja automobila emitiraju između 240 i 390 manje kilograma $\mathrm{CO}_{2}$ po osobi godišnje (Nijland i van Meerkerk, 2017).

Dijeljenje automobila ima pozitivan učinak na okoliš smanjenjem potreba za vlasništvom nad vozilom članova i broja kilometara koje su njegovi članovi putovali, kao i poticanjem na veće korištenje alternativnih načina putovanja (Katzev, 2003). Suprijevoz može pozitivno utjecati na ekonomski razvoj na način da može povećati ekonomsku produktivnost tako što osobama koje traže posao, a ne mogu si priuštiti osobno vozilo, omogućuje upotrebu automobila ako je potrebno za traženje posla i zapošljavanje (Litman, 2000). Rast usluga dijeljenja automobila kao novog i održivijeg načina prijevoza usmjerava privatno vlasništvo prema korištenju usluga (Ferrero et al., 2018). Zbog toga se suprijevoz javlja kao alternativa klasičnom obliku putovanja osobnim automobilom koja se temelji na načelu održivog razvoja.

Sukladno ranije navedenom cilj ovog rada je utvrditi stavove korisnika o suprijevozu u Republici Hrvatskoj. Dobiveni rezultati istraživanja poslužit će za utvrđivanje trenutnih preferencija korisnika kao i za uviđanje mogućnosti razvoja suprijevoza u prometnom sustavu Republike Hrvatske. Nakon uvodnog dijela, u sklopu drugog poglavlja analiziraju se karakteristike suprijevoza, odnosno definira se pojam suprijevoza te se analizira povijesni razvoj suprijevoza kao i modeli istoga. U sklopu trećeg poglavlja daje se pregled postojećih istraživanja, objašnjava se metodologija istraživanja i karakteristike uzorka, prezentiraju se rezultati provedenog primarnog istraživanja i iznose se ograničenja te preporuke za buduća istraživanja.

\section{KARAKTERISTIKE SUPRIJEVOZA}

\section{1 Pojmovno određenje suprijevoza}

U literaturi se spominju dva pojma koja označavaju suprijevoz, a to su carsharing i carpooling. Suprijevoz se može definirati kao zajedničko putovanje dviju ili više osoba do određene destinacije tako da svi suputnici ravnopravno dijele troškove vožnje (engl. carpooling) ili korištenje vozila 
organizacije koja posjeduje određeni broj osobnih automobila te nudi korisnicima mogućnost njihova korištenja pod određenim uvjetima (engl. carsharing) (Hirnig, Šikić i Gržin, 2017). Često dolazi do zablude između pojmova carsharing i carpooling koji se smatraju sinonimima, a nisu. lako se značajno razlikuju u svojim ciljevima, poslovnim modelima, tehnologiji koju koriste te tržištu na kojem nastupaju ti pojmovi koji označuju suprijevoz imaju neka zajednička obilježja (Millard-Ball et al., 2005):

- organiziranu grupu sudionika,

- jedno ili više dijeljenih vozila,

- decentraliziranu mrežu parkirnih lokacija smještenih blizu domova, radnih mjesta i stanica za prijevoz,

- unaprijed organizirano korištenje,

- najam za kratko vrijeme te

- samostalni pristup vozilu.

Pojam carsharing objedinjuje otvoreni pristup programu dijeljenih vozila koja su namijenjena povremenim putovanjima gdje je potreban automobil. Postoji razlika u govornim područjima engleskog jezika gdje definicija carsharinga ima različito značenje. U Velikoj Britaniji pojam carsharing podrazumijeva vozila u privatnom vlasništvu koja se dijele za određeno putovanje, dok se ta ista definicija u SAD-u odnosi na pojam carpooling. U SAD-u se za pojam carsharing koristi definicija vozila koja su u vlasništvu zasebne organizacije i koja se dijele između više različitih korisnika koji ih mogu koristiti u različito vrijeme. Ova definicija u Velikoj Britaniji opisuje pojam Car clubs (Millard-Ball et al., 2005). Pojam carsharing se često koristi u Europi. Litman (2000) opisuje carsharing kao uslugu najma automobila koja je namijenjena kao supstitut vozilu u privatnom vlasništvu.

\section{2 Prednosti i nedostaci suprijevoza}

Ukoliko postoji bilo kakva nacionalna, regionalna ili lokalna podrška za sustave dijeljenja automobila putem političkih tijela, ista se temelji na doprinosu suprijevoza smanjenju prometa (Loose, 2010). Dijeljenje automobila smanjuje emisije i smanjenjem putovanja vozila i korištenjem novijih vozila koja štede gorivo - u mnogim slučajevima hibrida (Millard-Ball et al., 2005). U prosjeku su vozila za dijeljenje automobila novija od većine osobnih vozila što utječe na stavranje manje štetnih tvari u zraku, manje štetnih tvari za zdravlje te manjom potrošnjom goriva (Loose, 2010). Nijland i van Meerkerk (2017) navode kako sudionici dijeljenja automobila emitiraju između 240 i 390 manje kilograma $\mathrm{CO}_{2}$ po osobi godišnje, a što predstavlja između $13 \%$ i $18 \%$ njihovih emisija $\mathrm{CO}_{2}$ u vezi $s$ vlasništvom automobila i upotrebom automobila. Otprilike trećina do polovice tog smanjenja može se pripisati manjoj uporabi automobila, a ostatak do nižeg stupnja vlasništva automobila.

Suprijevoz također može ispuniti potrebe posebnih tržišnih niša. Na primjer, male tvrtke mogu koristiti dijeljenje automobila kao učinkovitiju i fleksibilniju alternativu posjedovanja automobila. Navedeno se posebno odnosi na vozila koja se koriste samo povremeno ako se $u$ blizini ne nalazi uobičajena usluga iznajmljivanja automobila (Litman, 2000). Prednost sustava dijeljenja automobila 
predstavljaju i značajne uštede korisnika. Mnoga kućanstva i poslovna poduzeća pridružuju se programu za dijeljenje automobila jer mogu uštedjeti novac na prijevozu (Millard-Ball et al., 2005). Vlasništvo vozila glavni je trošak budžeta kućanstva koji može biti veliko opterećenje za kućanstva s umjerenim i niskim prihodima. Djelitelji automobila također mogu cijeniti vrijednost izbjegavanja zadataka održavanja i čišćenja vozila te sigurnosti bez neočekivanih računa za popravak (Litman, 2000).

Suprijevoz se ne može razviti sve dok se dovoljno potencijalnih korisnika u svakom području ne upozna s konceptom, ne shvati kako im to može koristiti te sve dok potencijalni korisnici ne razviju povjerenje u organizacije. Navedeno će zahtijevati obrazovanje i bolje marketinške aktivnosti. Organizacije koje pružaju usluge dijeljenja automobila također navode temeljni kapital kao jednu od prepreka kako bi bile osnovane. Ipak, suprijevoz podržava i podržan je od strane menadžmenta upravljanja potražnjom u prometu. Strategijama upravljanja potražnjom u prometu obuhvaćene su mjere kojima se povećava mogućnost putovanja i smanjuju poremećaji na tržištu kojima se potiče prekomjerno putovanje automobilima. Te strategije imaju sinergijski učinak što znači da su učinkovitije provedene zajedno nego odvojeno. Dugoročno gledano, one pomažu stvoriti raznovrsniji prometni sustav i smanjiti ovisnost o korištenju automobila u zajednici (Litman, 2000). Većina prepreka su lokalne, ali neka se pitanja bolje rješavaju na nacionalnoj razini. Mnogi su pružatelji usluge dijeljenja automobila izrazili interes za nacionalnom udrugom za dijeljenje automobila koja bi mogla pomoći u promicanju razumijevanja za regulatornu reformu i osigurati forum za umrežavanje i razmjenu podataka za operatora suprijevoza (Millard-Ball et al., 2005).

Političko ograničenje je $i$ to što je vjera u tehnologiju jača od podizanja svijesti o upravljanju mobilnošću. $U$ političkim se krugovima širi nada da će moderna tehnologija vozila riješiti trenutne probleme izazvane prometom. $U$ prošlosti je to, između ostalog, dovelo do spremnosti kreatora politika Europske unije kao i nacionalnih zakonodavaca da prihvate samoregulaciju u automobilskoj industriji radi smanjenja potrošnje goriva i povezane emisije $\mathrm{CO}_{2}$. Suprotno tome, popratne mjere, poput podizanja svijesti među vozačima kroz upravljanje mobilnošću i informaciijkim kampanjama, provedene su polusvijesno, ako su uopće provedene (Loose, 2010). Šolman, Presečki ¡ Zubić (2010) navode kako nedostatak predstavlja i to što postoji mogućnost da pojedini korisnici nemaju osiguranu povratnu vožnju u slučaju vremenske nepodudarnosti obaveza nekih korisnika u odnosu na druge, posebno kod neformalnog oblika dijeljenja automobila. Zatim, nastaje gubitak potpune slobode u planiranju i realizaciji osobnih putovanja te je nužno privikavanje na novi tip automobila kojim korisnik još nije upravljao.

\subsection{Povijesni razvoj i modeli suprijevoza}

U sklopu ovog potpoglavlja prvotno se daje kratak osvrt na povijesni razvoj suprijevoza, a zatim se pobliže objašnjavaju pojedini modeli suprijevoza.

\subsection{Povijesni razvoj suprijevoza}

Razvoj suprijevoza seže od 1940-ih godina kada je carsharing prvi put predstavljen. Kroz proteklih 80 godina, tržište dijeljenja automobila je u stalnom porastu kako su ljudi otkrivali da dijeljenje 
automobila predstavlja učinkovitu metodu za ublažavanje rastućih cijena goriva i vozila (Erceg, 2014). Povijest suprijevoza u Europi započela je 1948. godine pokušajem osnivanja carsharing programa u Zurichu u Švicarskoj kada je zadruga Sefage (njem. Selbstfahrergemeinschaft) počela s djelovanjem. Ovaj rani pothvat uglavnom je bio motiviran pojedincima koji si nisu mogli priuštiti kupnju vlastitog automobila, pa su ga umjesto toga podijelili s drugima. Nakon Sefage u Europi su se pojavilo nekoliko pokušaja carsharing eksperimenata koji su započeli, ali ubrzo prestali s radom. Jedna od takvih inicijativa bila je poznata kao Protocip koja je započela 1971. godine u Montpellieru u Francuskoj (Shaheen, Sperling i Wagner, 1998). Slične inicijative u Europi bile su Witkar u Amsterdamu 1973. godine, zatim Green cars u nekoliko mjesta u Velikoj Britaniji u kasnim 1970.-ima te Vivalla Bil u Örebru u Švedskoj 1983. godine (Millard-Ball et al., 2005).

Uspješna iskustva carsharinga u Europi započela su u 1980.-ima u Danskoj, Engleskoj, Francuskoj, Irskoj, Italiji, Norveškoj, Škotskoj i Švedskoj. Četiri najaktivnije zemlje u Europi su bile Švicarska, Austrija, Nizozemska i Njemačka gdje je otprilike 200 carsharing organizacija bilo aktivno u 300 gradova. Europska carsharing oganizacija (engl. Carsharing Association) osnovana je 1991. godine kako bi podržala carsharing lobističke aktivnosti te daljnji razvoj carsharing organizacija u Europi. lako su start-upovi carsharing organizacija bili subvencionirani, tipični operativni troškovi nisu bili subvencionirani u europskim carsharing organizacijama. Dvije najstarije carsharing organizacije su Mobility Car-Sharing Switzerland koja je proizašla iz pokušaja širenja dijeljenja automobila po četvrtima i tranzitnim stanicama u Švicarskoj; i StattAuto Berlin koji je uveden kao dio sveučilišnog istraživanja koje je pokazalo kako carsharing nudi održivu alternativu uobičajenom prijevozu u Njemačkoj (Shaheen, Sperling i Wagner, 1998).

Danas se suvremeno dijeljenje automobila proširilo na četiri kontinenta. Središnja Europa i dalje ostaje epicentar aktivnosti sustava dijeljenja automobila, a ostala rastuća tržišta razvila su se u Sjevernoj Americi, Aziji i Australiji. Carsharing je prisutan svugdje u svijetu uključujući oko 1000 gradova širom svijeta (MOVMI, 10.07.2019.). U Europi je sustav dijeljenja automobila prisutan u većini država, a to su: Austrija, Belgija, Danska, Finska, Francuska, Njemačka, Italija, Nizozemska, Norveška, Španjolska, Švedska, Švicarska; zatim Škotska, Engleska i Wales u Ujedinjenom Kraljevstvu te Kanada i Sjedinjene Američke Države u Sjevernoj Americi. Posljednjih godina trend dijeljenja automobila rapidno se razvija u Moskvi koja je sa 16500 vozila bila europski lider u 2018. godini, dok je na vrhu bio Tokio sa 19800 vozila (Wagner, 2. 7. 2019.). U Aziji je carsharing prisutan u Japanu i Singapuru, a takve organizacije nalazimo i u Australiji (Shaheen i Cohen., 2007).

\subsubsection{Modeli suprijevoza}

Suprijevoz odnosno sustav dijeljenja automobila širok je pojam koji obuhvaća mnoštvo različitih poslovnih i operativnih modela. U mnogočemu su ti modeli slični i usko povezani sa zemljopisnim kontekstom i ciljanim tržištem. Primjerice organizacije za dijeljenje automobila u ruralnim područjima obično su organizirane različito, možda na osnovi suradnje ili na dobrovoljnoj osnovi, i imaju drugačiji operativni model od onih u urbanim područjima (Millard-Ball et al., 2005).

Glavni modeli koji se javljaju u Sjevernoj Americi su (Millard-Ball et al., 2005): 
1. Profitni. Većina najvećih operatora u Sjevernoj Americi su u privatnom vlasništvu, odnosno to su profitna društva (Flexcar, Zipcar i Communato).

2. Neprofitni. Ovi operatori su inkorporirani u organizacije koje su oslobođene od plaćanja poreza (pr. City CarShare u San Franciscu i PhillyCarShare u Philadelphiji).

3. Kooperativni. Upravljani su od strane članova koji se pridružuju kupnjom udjela u organizaciji. U praksi, ovaj udio djeluje na sličan način kao povratni depoziti koje naplaćuju profitni i neprofitni operatori (pr. Cooperative Auto Network u Vancouveru).

Jedna od najvažnijih razlika između ova tri oblika organizacijske strukture odnosi se na izvore kapitala i osnivanja. Ključno pitanje koje treba riješiti bilo koja carsharing organizacija koja pokreće inicijativu jest odakle će doći kapital za financiranje. Svaka vrsta poslovanja ima jedinstvene izvore financiranja koje će možda moći iskoristiti, poput izravnih ulaganja, zaklada ili državnih potpora. Profitni pružatelji usluga suprijevoza najčešće imaju pristup rizičnom kapitalu ili drugim izvorima kao što su privatni start-up fondovi. Neprofitni operatori često imaju mogućnost iskorištavanja sredstava iz državnih fondova, a njihov status oslobođenja od poreza znači da mogu dobiti poticaje od države za svoje osnivanje. Kooperativne organizacijske strukture su djelomično ovisne o njihovim članovima koji osiguravaju kapital. Također, predložene su i druge različitosti među ovim organizacijskim modelima. Tako Brook (2004) tvrdi da postoji vjerojatnost da neprofitne i kooperativne organizacijske strukture možda neće imati poticaja za širenje poslovanja koliko i profitna poduzeća. $S$ druge strane, ističe da profitna poduzeća nisu baš najbolji primjer modela kojim bi se postigli usko navedeni ekološki ciljevi poput smanjenja putovanja vozila. Na primjer, nekoliko neprofitnih organizacija tvrdi da su njihove strukture cijena postavljene na način da obeshrabre nepotrebnu uporabu automobila naplaćivanjem svakog prijeđenog kilometra, a ne povezivanjem sati i kilometara u promotivne pakete. Neke partnerske agencije su zbog toga izrazile preferencije za suradnju s neprofitnim organizacijama. Neprofitne organizacije se također mogu lakše podržati jer njihov porezni status može smanjiti ciljeve zajednice u privatizaciji uličnog prostora prilikom odobravanja parkiranja na ulici za potrebe dijeljenja automobila. Međutim, profitne organizacije navode kako one postižu slične ekološke ciljeve - "čineći dobro, radeći dobro" (Millard-Ball et al., 2005).

Širom svijeta uvedeni su programi franšize, outsourcinga i replikacije u dijeljenju automobila kako bi se dodatno promovirala upotreba carsharinga (Erceg, 2014). Flexcar, na primjer, vodi Flexcar Network pod kojim lokalni operatori poput I-GO-a u Chicagu, imaju ugovore s Flexcar-om koji im osigurava opskrbu vozila, tehnologije i back-office funkcija kao što je naplata. Prema Flexcar-u franšize imaju smisla na manjim tržišstima gdje tvrtke možda neće htjeti samostalno obavljati određene operacije. U Kanadi, Communato je razvio dvojezični sistem pod nazivom Réservauto koji je dizajniran sa svrhom prilagođavanja različitim potrebama drugih carsharing operatora. Međutim, City CarShare iz San Francisca, ima nacionalni replikacijski program kako bi pružio tehničku pomoć neprofitnim operatorima u drugim regijama. Primjer takvog programa je PhillyCarShare koji je bio osnovan s ovakvom podrškom. 2005. godine City CarShare objavio je priručnik za pomoć novim odnosno start-up carsharing operatorima pokrivajući niz detalja vezanih uz probleme operativnog i poslovnog planiranja. Franšize i slični aranžmani su možda najbolje razvijeni u Europi. Primjerice, 
njemački Cambio počeo je poslovati u Aachenu i Bremenu 1990. godine. Od tada je tvrtka Cambio razvila zajedničko ulaganje kako bi pružila svoje usluge u četiri dodatna grada u Njemačkoj i Belgiji te osigurala programsku podršku i pozivni centar u sedam drugih gradova. U Italiji, Iniziativa Car Sharing (ICS) je izravni davatelj usluga podrške i tehnologije uključujući nacionalni pozivni centar. Iniziativa Car Sharing je konzorcij od 18 gradova i provincija osnovan od strane Ministarstva okoliša, ali individualni operatori potječu iz javnog i privatnog sektora (Millard-Ball et al., 2005).

Erceg (2014) navodi podjelu carsharing na tri modela:

- neighborhood carsharing (dijeljenje automobila u susjedstvu),

- station carsharing programi odnosno vozila namijenjena osobama koje žive izvan metro zone i putuju svakodnevno na posao i sa posla,

- multi-nodal carharing programi.

Neigrborhood carsharing ili dijeljenje automobila u susjedstvu je nastao u Europi i osnovni je model suprijevoza (Erceg, 2014). Uključuje programe koji se fokusiraju na zapošljavanje kao i na stambeno tržište. Pojam "neighborhood" odnosno susjedstvo koristi se kako bi se ovaj program razlikovao od ostalih programa dijeljenja vozila kao što su station cars (Millard-Ball et al., 2005). U ovom modelu vozila su često smještena u stambenim objektima susjedstva i rjeđe u poslovnim područjima, a troškovi korištenja i vozila dijele se između skupine pojedinaca. Glavno obilježje ovog modela je da rezultira povećanom tranzitnom spremnošću takve vožnje jer korisnici postaju svjesniji pojedinačnih troškova svakog putovanja (Erceg, 2014).

Za razliku od dijeljenja automobila u susjedstvu koje služi širokom izboru putovanja, station cars programi fokusiraju se na vezu između tranzitne stanice i doma i/ili radnog mjesta. Pružaju automobil u "kućnom kraju" omogućujući prijevoznicima da se ujutro odvezu na stanicu, a drugi dio puta se voze tranzitnom linijom na posao. Zatim, isti automobil koristi dolazeći željeznički putnik za putovanje od tranzita do svojeg radnog mjesta koje je izvan pješačke udaljenosti. $\mathrm{Na}$ primjer, u CarLinku u San Franciscu, automobil je također dostupan za zaposlenike tijekom radnog dana. Ista putovanja navečer se događaju obrnutim redoslijedom, s automobilom smještenim tijekom noći u rezidenciji korisnika (Millard-Ball et al., 2005). Karakteristika ovog modela je nizak omjer broja korisnika prema broju vozila u odnosu na ostale modele carsharinga. 1990.-ih godina ovaj model je bilježio rast na području Azije zbog integracije elektroničkih tehnologija (Erceg, 2014). Glavna razlika između neighborhood carsharinga i station cars-a je u tipovima korisnika i vrstama putovanja. Station cars usredotočeni su na tržište svakodnevnih putovanja na posao sa plaćanjem mjesečne pretplate. Nadalje, stacionarni automobili imaju definirane skupine korisnika - home-based korisnike (korisnici smješteni kod kuće) i work-based korisnike (korisnici smješteni na radnom mjestu) te u nekim novijim modelima i podnevne korisnike. $S$ druge strane, svako carsharing vozilo uslužuje puno širu bazu članova i plaćanje je obično po uporabi vozila. Također, ovakav program je pomogao carsharing tvrtkama zaraditi dovoljno prihoda kako bi nastavili poslovati sa jako malo ili čak bez subvencija (Millard-Ball et al., 2005).

Treća vrsta modela suprijevoza je multi-nodal carsharing koji se odnosi na više-čvorišna vozila za zajedničku uporabu koja se voze između više stanica i obično su povezana s odmaralištima, 
nacionalnim parkovima i kampusima sveučilišta. Ovaj model može bit povezan $\mathrm{s}$ tranzitom, a njegova prednost je ta što se može koristiti za jednosmjerna putovanja umjesto dvosmjernih putovanja, kao i kod neighborhood carsharing programa. Ovim modelom uvedena je fleksibilnost za korisnike, ali se povećala složenost upravljanja sustava dijeljenja automobila zbog potrebe premještanja vozila na druge lokacije (Erceg, 2014).

\section{ISTRAŽIVANJE STAVOVA KORISNIKA O SUPRIJEVOZU U REPUBLICI HRVATSKOJ}

\section{1 Pregled literature}

Umjesto da kupuju i posjeduju stvari, potrošači žele pristup robi i radije plaćaju iskustvo privremenog pristupa njima. Vlasništvo više nije krajnji izraz želje potrošača. Potrošnja na temelju pristupa definira se kao transakcije koje mogu biti tržišno posredovane u kojima se ne vrši prijenos vlasništva. Potrošač stječe vrijeme potrošnje $s$ artiklom, a u slučajevima tržišno posredovanih pristupa spreman je platiti određenu cijenu za uporabu tog predmeta. Potrošači mogu pristupiti objektima ili mrežama koje si ne bi mogli priuštiti ili koje nisu odlučili posjedovati zbog zabrinutosti kao što su prostorna ograničenja ili okoliš. U usporedbi sa svojim proizvodima koji posjeduju, potrošači ostvaruju koristi kupujući proizvode ili usluge izravno iliulaze u mrežu na temelju plaćanja, iznajmljivanja ili pristupa. Primjeri modela pristupa vidljivi su također i u programima dijeljenja automobila (Zipcar). U dijeljenju automobila potrošači pristupaju automobilima u vlasništvu tvrtke, što ga razlikuje od programa za zajedničko korištenje automobilom ili od strane peer-to-peer dijeljenja automobila, kao što je RelayRides. Dijeljenje automobila jedan je od najvažnijih konteksta koji se temelje na pristupu današnjem tržištu (Bardhi i Eckhardt, 2012). Omogućujući pristup vozilu za povremena putovanja, dijeljenje automobila omogućava kućanstvima da se odreknu automobila ili drugog vozila. Millard-Ball i suradnici (2005) naglašavaju kako u prosjeku, otprilike $20 \%$ članova carsharinga to čine, uz još više odustajanja od kupnje novog automobila. Dakle, najmanje pet privatnih vozila je zamijenjeno jednim vozilom za dijeljenje, a mnoga istraživanja pokazuju znatno veće koristi (Martin, Shaheen i Lidicker, 2010; Shaefers, 2013; Kopp, Gerike i Axhausen, 2015). Zbog toga, smanjeno vlasništvo nad vozilima može dovesti do veće dostupnosti parkiranja i manje potrebe za novim parkiralištima. Šire prednosti smanjenog parkiranja uključuju uštedu troškova, oslobađanje zemljišta za razvoj i manje otjecanja oborinskih voda (MillardBall et al., 2005). Suprijevoz je u posljednjem desetljeću znatno porastao u Sjevernoj Americi i procvjetao u metropolitanskim regijama diljem SAD-a i Kanade. Novi transportni ambijent nudi gradskim stanovnicima alternativu za automobil, onaj bez vlasništva nad automobilom. Dijeljenje automobila eliminira potrebu za fiksnim troškovima vlasništva. Gradski stanovnici koji ovise o automobilima mogu uštedjeti novac i prilagoditi se načinu života manje ovisnom o automobilima (Martin, Shaheen i Lidicker, 2010).

Nijland i van Meerkerk (2017) navode da je 37 \% ispitanika koji su već posjedovali automobil izjavilo da bi kupilo još jedan da nije započelo dijeljenje automobila. Oni koriste zajednički automobil kao dodatni automobil. Od onih koji nisu posjedovali automobil, 8 \% bi ih kupilo da nisu započeli dijeljenje automobila. Ukoliko se gleda ukupni učinak za obje skupine, vlasništvo 
automobila smanjilo se sa 1,12 automobila po domaćinstvu na 0,72 . Za 57 \% ispitanika, zajednički automobil funkcionirao je kao drugi ili treći automobil. Dijeljenje automobila značajno smanjuje posjed vozila u kućanstvima, usprkos činjenici da je 60 \% svih domaćinstava koja se pridružuju dijeljenju automobila bez automobila (Martin, Shaheen i Lidicker, 2010). Važno je istaknuti da carsharing služi kao dopuna postojećem javnom gradskom prijevozu, te da on nije nužno zamjena za posjedovanje osobnog automobila. Naravno, sve ovisi o razlozima posjedovanja osobnog automobila. lako u odnosu na pješačenje i bicikliranje carsharing sustav ima negativne utjecaje na okoliš (postoji opasnost od prometnih nesreća, a buka i emisije štetnih plinova, osim u slučaju uporabe električnih vozila, i dalje postoje), navedeni utjecaji daleko su manji jer primjena ovog sustava dovodi do smanjenja prijeđenih kilometara i smanjenja broja vozila na cestama, a samim time i do smanjenja gužvi u prometu. Pritom korisnici i dalje uživaju u svim prednostima koje inače nudi posjedovanje osobnog vozila (komfor vožnje i fleksibilnost kretanja) te se može reći da primjena sustava dijeljenja automobila pridonosi povećanju mobilnosti uz ublažavanje posljedica koje ubrzan razvoj cestovnog prometa sa sobom donosi (Hirnig, Šikić i Gržin, 2017).

Katzev (2003) je proveo istraživanje kako bi ispitao kojim faktorima su osobe bili motivirane za učlanjenje u car sharing organizaciji u Portlandu. $U$ ispitivanju su sudjelovale osobe kojima je to bila prva godina članstva. Većina (59 \%) članova carsharing programa izjavila je kako nisu posjedovali osobno vozilo u trenutku kada su se pridružili organizaciji, dokje manje od polovice (41\%) reklo da su vlasnici. Najveći broj članova bio je prvenstveno motiviran za pridruživanje carsharing programima zbog periodične potrebe za dodatnim vozilom. Kao drugi razlog ispitanici navode financijske uštede za koje su očekivali da će nastati izbjegavanjem troškova posjedovanja i upravljanja osobnim vozilom ili nepotrebne kupnje vozila. Raspoloživost vozila rijetko je predstavljala problem tijekom prve godine korištenja carsharing programa, kada se odnos članova prema vozilima održavao na 13:1. Postoji vrlo malo osnove za zabrinutost zbog prekomjernih last-book rezerviranja, jer je 60 $\%$ rezervacija izvršeno najmanje jedan ili dva dana prije korištenja. Suprotno tome, samo $13 \%$ rezervacija je napravljeno 30 minuta ili manje prije traženog vremena odlaska. Mnogi ispitanici naveli su kako su alternativne načine prijevoza (npr. javni prijevoz, šetnje i biciklizam) često koristili za odlazak na posao i kupovinu. Loose, Mohr i Nobis (2006) proveli su istraživanje u svrhu procjene mogućnosti daljnjeg razvoja dijeljenja automobila u Njemačkoj. Rezultati su ukazali na potencijalni rast korištenja usluga dijeljenja automobila, naročito u poslovne svrhe. $U$ usporedbi $s$ rezultatima istraživanja provedenog u 2002. godini zabilježen je značajan rast u broju korisnika (za $18 \%$ ), u broju ljudi s pristupom dijeljenju automobila (za 33 \%) te u porastu broja stanica za razmjenu automobila (za $31 \%$ ). Takvi rezultati potvrda su da se radi o novom tržišnom trendu i kako je za očekivati da će se tržište dijeljenja automobila nastaviti rapidno razvijati (Loose, Mohr i Nobis, 2006). Motive i motivacijske obrasce na kojima se temelji korištenje dijeljenja automobila istraživao je Shaefers (2013), a koristeći pri tome kvalitativni pristup. Cilj je bio identificirati temeljne hijerarhijske povezanosti atributa dijeljenja automobila i temeljnih vrijednosti kupaca. Temeljem rezultata identificirana su četiri osnovna motivacijska obrasca: traženje vrijednosti, praktičnost, stil života i okoliš. Osim utilitarističkih motiva traženja i praktičnosti, afektivni ili simbolički motiv stila života utječe na prihvaćanje i upotrebu potrošača dijeljenja automobila. Boyaci, Zografos i Geroliminis (2015) predstavili su model za planiranje jednosmjernih sustava dijeljenja vozila uzimajući u obzir potrebe za premještanjem vozila i električnim punjenjem vozila. Predloženi 
model istodobno razmatra neto koristi i operatora i korisnika. Model pruža donosiocima odluka mnogo mogućnosti za provođenje analize osjetljivosti za relevantne parametre modela. Ova je značajka posebno korisna za vrijednosti troškova koje je teško empirijski utvrditi (pr. korisni dobitak zadovoljnih kupaca, pokrivenost stanovništva, troškovi pristupačnosti stanica).

Hirnig, Šikić i Gržin (2017) istraživali su upoznatost ispitanika s pojmovima carpooling i carsharing na području Republike Hrvatske. Cilj istraživanja bio je i saznati koriste li ispitanici carpooling te ukoliko ne koriste bi li postali potencijalni korisnici. Najveći udio ispitanika (39,3\%), iako ima vozačku dozvolu, ne posjeduje automobil te isti imaju samo ponekad na raspolaganju. Većina ispitanika uslugu carpoolinga koristi vrlo rijetko, a najviše ispitanika (87 \%) carpooling koristi povremeno. Carpooling se pretežno koristi za neka povremena putovanja, vjerojatno na duže relacije, pri čemu su značajnije financijske uštede. Uvažavajući cilj smanjenja gužvi na cestama, posebice tijekom vršnih sati, neophodno je putnike potaknuti na korištenje carpoolinga prilikom svakodnevnih migracija (posao, fakultet i sl.), što za sad nije dovoljno čest slučaj u Republici Hrvatskoj. Ono što dodatno ohrabruje i ukazuje na potencijal razvoja je činjenica da od 129 ispitanika (70,5\%) koji nisu nikada koristili carpooling, samo ih je 19 (14,7 \%) navelo kako uslugu ne bi koristilo u budućnosti. Očekivano najviše zainteresirane za ovaj oblik prijevoza osobe su koje imaju vozačku dozvolu, ali nemaju automobile na raspolaganju.

\subsection{Metodologija i uzorak istraživanja}

U svrhu ostvarivanja cilja rada provedeno je primarno istraživanje, a čija je svrha bila istražiti stavove korisnika o suprijevozu u Republici Hrvatskoj. Kao instrument u primarnom istraživanju korišten je visoko strukturirani anketni upitnik napravljen u Google obrascu. Poziv na sudjelovanje u istraživanju slan je na email adrese mladih ispitanika odnosno primarno studenata na Ekonomskom fakultetu u Zagrebu koji su bili zamoljeni da anketni upitnik distribuiraju svojim poznanicima (metoda snježne grude). Istraživanje je provedeno u kolovozu 2020. godine na uzorku od 205 ispitanika na području Republike Hrvatske. Anketni upitnik sastavljen je od 18 pitanja, od čega su 3 pitanja bila usmjerena na sociodemografske karakteristike ispitanika te su kod istih ispitanici mogli odabrati jedan od ponuđenih odgovora. Upoznatost ispitanika s pojmom suprijevoza te navikama vezanim uz putovanje ispitivana je kroz 10 pitanja, a kroz 5 tvrdnji ispitanici su izrazili svoju razinu slaganja vezano uz određene karakteristika suprijevoza.

U istraživanju je sudjelovalo 205 ispitanika, od čega su $60,5 \%$ bile osobe ženskog spola, a ostalih $39,5 \%$ činili su muškarci. 
Grafikon 1. Struktura ispitanika prema dobi

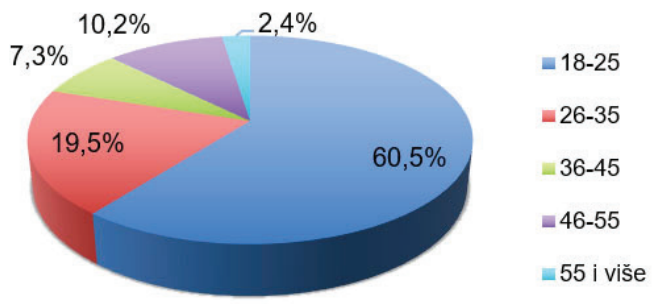

Izvor: primarno istraživanje

Kao što se može uočiti na grafikonu 1 najveći broj ispitanika (124) bio je starosti od 18 do 25 godina, dok je najmanje ispitanika (2,4\%) bilo starosti 55 godina i više. Najveći udio ispitanika (36,1\%) ima srednjoškolsko obrazovanje, a najmanji broj ispitanika ima završeno osnovnoškolsko obrazovanje (1,5\%). Mjesečna primanja u visini do 2.000 kn ima 28,8 \% ispitanika. Nakon toga, slijede ispitanici sa mjesečnim primanjima u rasponu 4.001 - 6.000 kn (21\%). Ispitanici koji imaju mjesečna primanja u iznosu 2.000 - 4.000 kn čine $17,6 \%$, slijede ispitanici sa mjesečnim primanjima u visini 6.001 - 8.000 kn (12,2\%), te osobe čija primanja iznose više od 10.000 kn (11,7\%), a najmanje je onih koji imaju primanja u rasponu 8.001 - 10.000 kn (8,8 \%).

\subsection{Rezultati istraživanja}

Od ukupnog broja sudionika, njih 106 (51,7\%) odgovorilo je da nisu upoznati pojmom suprijevoza, dok je njih 99 odnosno 48,3\% odgovorilo potvrdno. Od 205 ispitanika, njih 127 (62 \%) izjavilo je da posjeduje osobni automobil, a njih 78 (38 \%) izjavilo je kako ne posjeduju osobni automobil. lako je upoznatost sa pojmom suprijevoza relativno zadovoljavajuća, ipak je 84,4\% ispitanika navelo kako nije koristilo uslugu suprijevoza, dok je samo 15,6 \% ispitanika izjavilo da je koristilo uslugu takve vrste prijevoza.

Najčešći razlog korištenja suprijevoza zbog kojeg ispitanici koriste suprijevoz ili bi ga koristili su, kao što je i očekivano, manji troškovi (65,4\%). Kao drugi razlog korištenja slijedi izostanak problema s traženjem parkirnog mjesta (49,8\%). Neki od ostalih razloga koje ispitanici navode su doprinos smanjenju zagušenja u prometu (29,8 \%), neučinkovit javni prijevoz (26,8 \%) te doprinos zaštiti okoliša (24,4\%). Usluge suprijevoza 26 ispitanika koristi povremeno, a isti broj ispitanika (7) koristi suprijevoz jednom mjesečno i 2 - 3 puta tjedno. Samo jedan ispitanik je naveo kako koristi suprijevoz jednom tjedno. 
Grafikon 2. Korištenje ostalih oblika prijevoza prije početka korištenja usluge suprijevoza

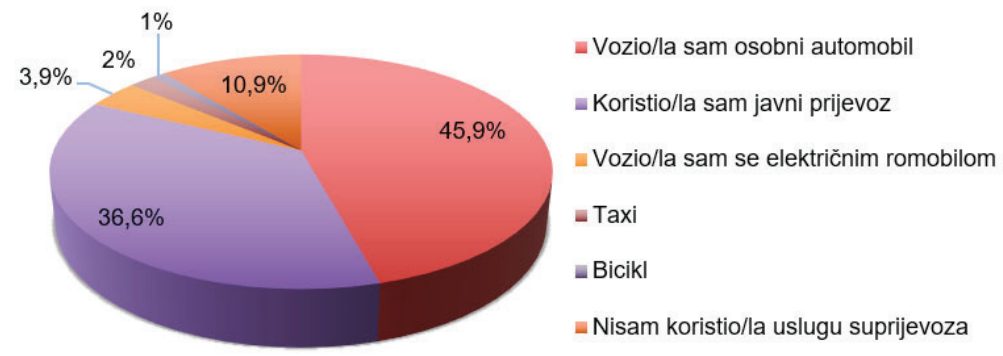

Izvor: primarno istraživanje

Prije korištenja usluge suprijevoza najviše ispitanika vozilo je osobni automobil (45,9\%), dok ih je $36,6 \%$ koristilo usluge javnog prijevoza (vidi Grafikon 2).

Grafikon 3. Razlozi korištenja suprijevoza

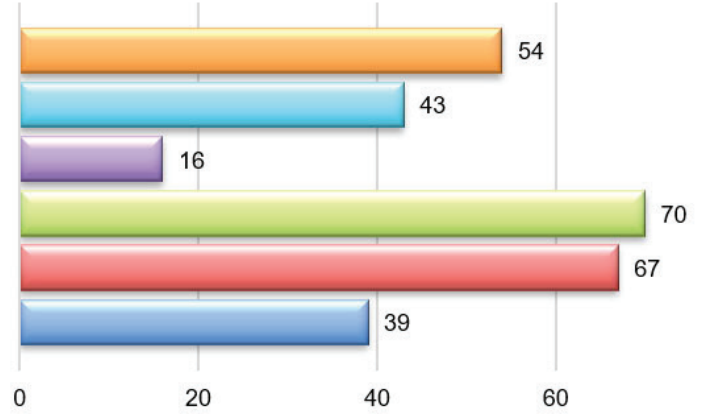

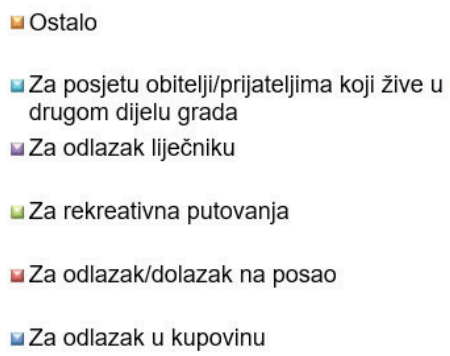

80

Izvor: primarno istraživanje

Najčešći razlog korištenja suprijevoza jesu rekreativna putovanja, a potom odlazak/dolazak na posao. Za posjetu obitelji ili prijateljima koji žive u drugom dijelu grada 43 ispitanika koristi ili bi koristilo suprijevoz, a njih 39 bi isti koristilo za odlazak u kupovinu. Samo 16 ispitanika koristilo bi suprijevoz za odlazak liječniku (vidi Grafikon 3).

Grafikon 4. Prosječna dnevna udaljenost prijeđena automobilom

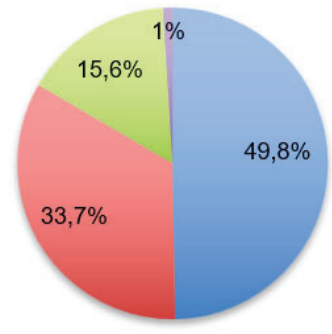

Izvor: primarno istraživanje 
U prosjeku, najviše ispitanika dnevno prijeđe manje od $20 \mathrm{~km}$ (49,8\%), udaljenost od 20 do $50 \mathrm{~km}$ prijeđe $33,7 \%$ ispitanika, $15,6 \%$ njih prijeđe od 50 do $100 \mathrm{~km}$ automobilom, a samo $1 \%$ ispitanika dnevno prelazi udaljenost veću od $100 \mathrm{~km}$ (vidi Grafikon 4).

\section{Grafikon 5. Stavovi ispitanika o suprijevozu}

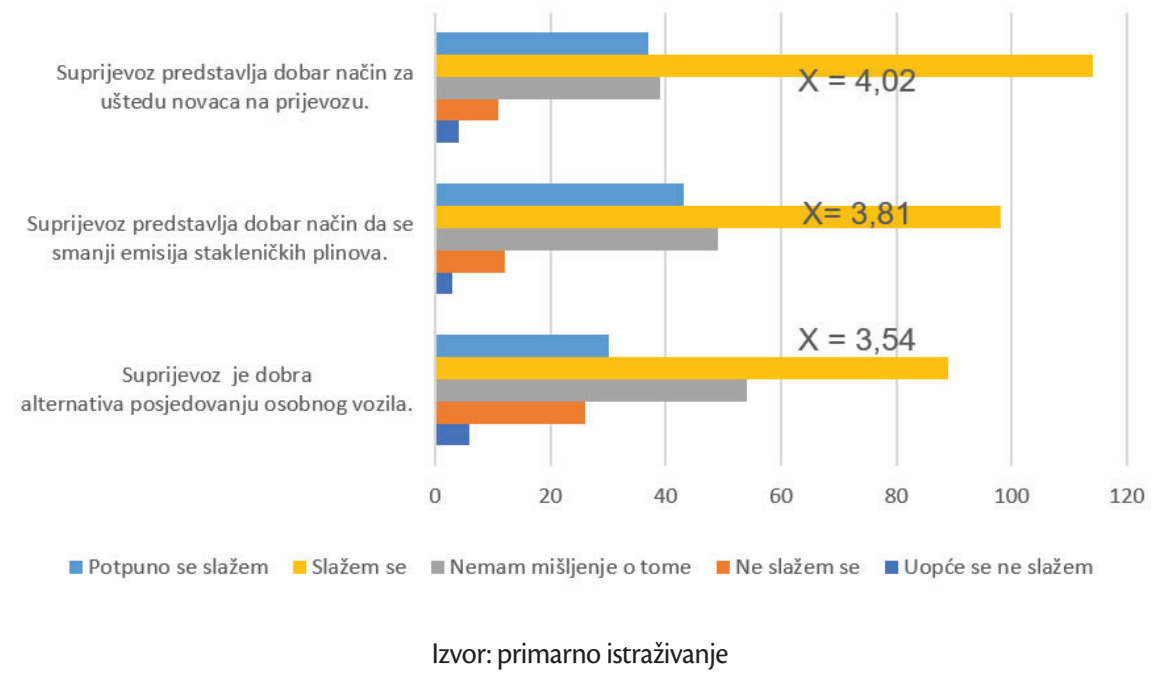

Kao što se može uočiti na grafikonu 5 najviše ispitanika (114) smatra kako suprijevoz predstavlja dobar način za uštedu novaca na prijevozu. Upravo su navedenu tvrdnju ispitanici i ocijenili u prosjeku s najvećom ocjenom $(x=4,02)$. Ispitanici su najmanje suglasni s tvrdnjom kako je suprijevoz dobra alternativa posjedovanju osobnog vozila $(x=3,54)$. Na pitanje „Koje je najduže vrijeme koje biste bili spremni izdvojiti da bi došli pješice od svog doma do lociranog vozila?" 39 \% ispitanika je odgovorilo kako bi bili spremni hodati do vozila 5 - 10 min; 38 \% nih izdvojili bi 1 - 5 minuta, 18 \% bi izdvojilo 10 - 15 min, a samo 4,9\% njih bi bio spremno izdvojiti 15 - 30 minuta vremena kako bi došli do lociranog vozila.

Pozitivno je što je od 129 ispitanika koji su naveli kako nikada nisu koristili usluge suprijevoza, njih $110(85,27 \%)$ navelo kako se ima namjeru u budućnosti koristiti uslugama istog. 
Grafikon 6. Stavovi ispitanika glede dijeljenja prijevoza

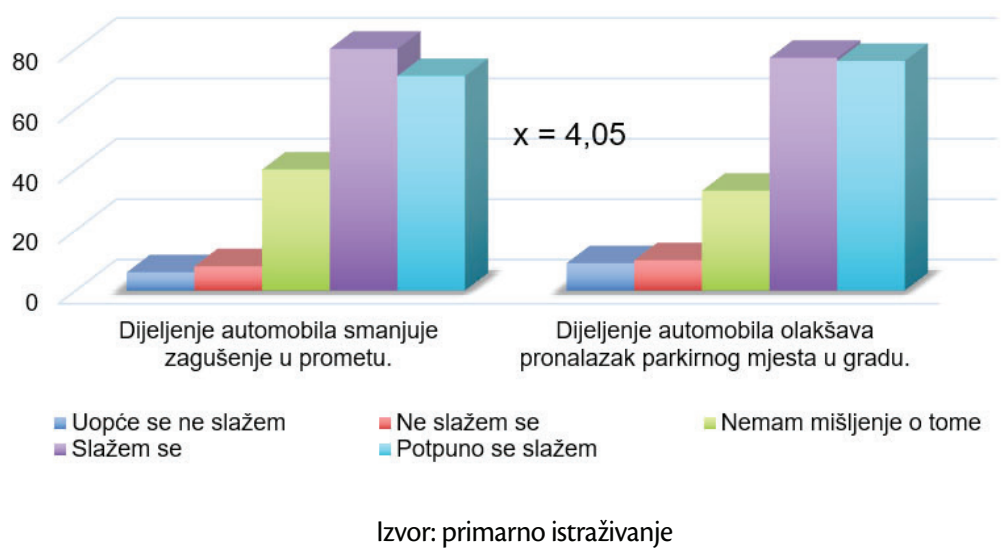

$34,6 \%$ ispitanika u potpunosti se slaže s tvrdnjom da dijeljenje automobila smanjuje zagušenje u prometu, dok je onih koji se uopće ne slažu 2,9\%. Više od trećine ispitanika (37,1 \%) potpuno se slaže s tim da suprijevoz olakšava pronalazak parkirnog mjesta u gradu, a 4,4 \% smatra potpuno suprotno i ne slaže se s navedenim. Na grafikonu 6 se može uočiti kako su ispitanici u prosjeku s jednakom ocjenom ocijenili razmatrane benefite korištenja suprijevoza.

\subsection{Ograničenja i preporuke za buduća istraživanja}

Ograničenja koja se pojavljuju u provedenom empirijskom istraživanju u sklopu ovog rada odnose se na manji uzorak kojeg je obuhvatilo ovo istraživanje (205 ispitanika) na području Republike Hrvatske te se zbog toga rezultati istraživanja ne mogu generalizirati ili koristiti na europskoj razini ili globalnoj razini. Još jedno ograničenje ovog istraživanja predstavlja manji udio mlađe populacije, odnosno učenika mlađih od 18 godina kao i umirovljenika koji bi također mogli biti potencijalni korisnici suprijevoza. Nedostatak je i to što se anketa provodila online putem društvenih mreža čime je na neki način zapostavljena starija populacija koja Internet i društvene mreže koristi u manjoj mjeri. Zbog istaknutih ograničenja teško je donositi zaključke o svim korisnicima i potencijalnim korisnicima na području Republike Hrvatske.

Znanstveni doprinos ovog istraživanja ogleda se u sistematizaciji postojećih saznanja o suprijevozu, kao iznimno zanimljivom trendu koje posljednjih godina sve više dobiva na značaju. Uzevši u obzir kako se i brojni gradovi na teritoriju Republike Hrvatske susreću s problemom prometnih zagušenja zbog neadekvatne prometne infrastrukture, razmatranje stava korisnika prema suprijevozu svakako je vrlo korisno. Obzirom na nedostatak istraživanja ove teme, a kako je provedeno istraživanje eksplorativne prirode sugerira se da se u budućnosti i dalje istraži ova tema.

Preporuka za buduća istraživanja bila bi provesti istraživanje i na druge načine, ne samo putem Interneta kako bi se obuhvatile i druge dobne skupine. Bilo bi korisno obuhvatiti veći uzorak kako bi rezultati istraživanja bili reprezentativniji i precizniji. Takvi podaci mogli bi se koristiti za usporedbu s inozemnim (europskim i svjetskim) istraživanjima na ovu temu. Također, budući da 
je Republika Hrvatska poznata turistička destinacija, u istraživanje bi bilo dobro uključiti i turiste koji dođu na odmor bez svog automobila, kao i segment poslovnih putnika koji su isto potencijalni korisnici suprijevoza.

\section{ZAKLJUČAK}

Danas je mobilnost od velikog značaja u urbanim područjima. Sve veći broj stanovnika i njihova potreba za putovanjima te porast broja automobila postaju opterećenje za gradove koji prvotno nisu bili dizajnirani kako bi mogli zadovoljiti te rastuće potrebe za mobilnošću. Posljedice toga su problemi zagušenja u prometu, zagađenje okoliša, prevelika potrošnja neobnovljivih izvora energije te buka koja stvaraju vozila čime se smanjuje kvaliteta života u urbanim područjima. Također, kao još neki problemi javljaju se rastući troškovi goriva, problem pronalaska parkirnog mjesta u gradu te troškovi posjedovanja osobnog automobila. Suprijevoz ili sustav dijeljenja automobila javlja se kao moguće rješenje navedenih problema jer dovodi do reduciranja broja osobnih automobila kao i do povećane mobilnosti, smanjenja emisije štetnih plinova te snižavanja troškova za korisnike.

U vrijeme provođenja istraživanja carsharing organizacije su prisutne u Zagrebu (Spin city) i u Dubrovniku (Avant2Go). Rezultati istraživanja stavova korisnika na području Republike Hrvatske pokazuju kako je upoznatost ispitanika s pojmom suprijevoza zadovoljavajuća (48,3\%), ali još uvijek je visok udio $(51,7 \%)$ onih koji nisu upoznati s tim pojmom. Navedeno upućuje kako bi trebalo educirati korisnike o takvom alternativnom obliku prijevoza.

Prije korištenja usluge suprijevoza najviše ispitanika vozilo je osobni automobil (45,9 \%), a 36,6 \% je koristilo javni prijevoz. Uslugu dijeljenja automobila trenutno koristi 15,6\% korisnika, što je relativno malo, a najviše ju koriste povremeno (80 \%) te zbog manjih troškova iza rekreativna putovanja. Ipak, ohrabruje činjenica da suprijevoz ima potencijal daljnjeg razvoja jer od $84,4 \%$ ispitanika koji nikad nisu koristili uslugu suprijevoza, njih 140 (78,2 \%) razmislilo bi o korištenju takve usluge. Isto tako, ispitanici se u velikoj mjeri slažu s tvrdnjama da je suprijevoz dobra alternativa osobnom vozilu, da smanjuje emisiju štetnih plinova, olakšava pronalazak parkirnog mjesta, smanjuje zagušenje u prometu te da dovodi do uštede novca u prijevozu. Navedeno upućuje na svjesnost ispitanika o pozitivnim stranama suprijevoza što bi trebalo iskoristiti kroz bolje promotivne i edukacijske mjere kako bi se potaknuo razvoj i popularizirao ovakav oblik prijevoza u Republici Hrvatskoj.

\section{LITERATURA}

Bardhi, F., Eckhardt, G. M. (2012) "Access-Based Consumption: The Case of Car Sharing", Journal of Consumer Research, 39(4), str. 881-898. doi: https://doi.org/10.1086/666376

Boyacı, B., Zografos, K. G., Geroliminis, N. (2015) "An optimization framework for the development of efficient one-way car-sharing systems", European Journal of Operational Research, 240(3), str. 718-733. Doi: https://doi.org/10.1016/j. ejor.2014.07.020

Brook, D. (2004) Carsharing - Start Up Issues and New Operational Models, Washington D.C.: Transportation Research Board

Erceg, A. (2014) "Carsharing situation in Croatia", Ekonomski vjesnik, 27(1), str. 183-195

Ferrero, F., Perboli, G., Rosano, M., Vesco, A. (2018) "Car-sharing services: An annotated review. Sustainable Cities and Society", 37(veljača), str. 501-518. doi: https://doi.org/10.1016/j.scs.2017.09.020 


\section{Naletina, I. Kovačc, D. Palić: Empirijsko istraživanje stavova korisnika o suprijevozu u Republici Zbornik Veleučilišta u Rijeci, Vol. 9 (2021), No. 1, pp. 345-361}

Fournier, G., Seign, R., Goehlich, V., Bogenberger, K. (2015) "Car-sharing with electric vehicles: a contribution to sustainable mobility?", Interdisciplinary Management Research, 11, str. 955-975

Hirnig, S., Šikić, L., Gržin, E. (2017) “Sustavi dijeljenja vožnji u funkciji smanjenja prometnih zagušena uz zadržavanje dostignute razine mobilnosti stanovništva", Zbornik Veleučilišta u Rijeci, 5(1), str.107-124. doi: https://doi. org/10.31784/zvr.5.1.8

Katzev, R. (2003) "Car Sharing: A New Approach to Urban Transportation Problems", Analyses of Social Issues and Public Policy, 3(1), str. 65-86. doi: https://doi.org/10.1111/j.1530-2415.2003.00015.x

Kopp, J., Gerike, R., Axhausen, K. W. (2015) "Do sharing people behave differently? An empirical evaluation of the distinctive mobility patterns of free-floating car-sharing members", Transportation, 42(3), str. 449-469. doi: https:// doi.org/10.1007/s11116-015-9606-1

Litman, T. (2000) "Evaluating Carsharing Benefits", Transportation Research Record, 1702(1), str 31-35. doi: https://doi. org/10.3141\%2F $1702-04$

Loose, W. (June 2010)The State of European Car-Sharing: Final Report D 2.4 Work Package 2. Bundesverband CarSharing. Dostupno na: https://www.motiva.fi/files/4138/WP2_Final_Report.pdf(12. 9. 2020.).

Loose, W., Mohr, M., Nobis, C. (2006) "Assessment of the Future Development of Car Sharing in Germany and Related Opportunities", Transport Reviews, 26(3), str. 365-382. doi: https://doi.org/10.1080/01441640500495096

Martin, E., Shaheen, S., Lidicker, J. (2010) "Impact of Carsharing on Household Vehicle Holdings: Results from North American Shared-Use Vehicle Survey", Transportation Research Record, 2143(1), str. 150-158. doi: https://doi. org/10.3141\%2F2143-19

Millard-Ball, A., Murray, G., Ter Schure, T., Fox, C. (2005) Car-sharing: Where and how it Succeeds, Washington D.C.: Transportation Research Board

MOVMI (10. 7. 2019.) Carshring market \& growth analysis 2019 (online). Dostupno na: https://movmi.net/carsharingmarket-growth-2019/ (3. 11. 2020.)

Nijland, H., van Meerkerk, J.(2017) “Mobility and environmental impacts of car sharing in the Netherlands", Environmental Innovation and Societal Transitions, 23(lipanj), str. 1-8. doi: https://doi.org/10.1016/j.eist.2017.02.001

Shaefers, T. (2013) "Exploring carsharing usage motives: A hierarchical means-end chain analysis", Transportation Research Part A, 47(siječanj), str. 69-77. doi: https://doi.org/10.1016/j.tra.2012.10.024

Shaheen, S. A., Cohen, A. P. (2007) "Growth in Worldwide Carsharing An International Comparison", Transportation Research Record: Journal of the Transportation Research Board, 1992(1), str. 81-89. doi: https://doi. org/10.3141\%2F $1992-10$

Shaheen, S., Sperling, D., Wagner, C. (1998) Carsharing in Europe and North American: Past, Present, and Future. Berkeley: University of California Transportation Center.

Šolman, S., Presečki, A., Zubić, I. (2010) “Dijeljenje osobnog automobila - uloga, perspektive i mogućnosti u hrvatskom prometnom sustavu,, U: Šolman, S., Presečki, A. i Zubić, I. (ur.) KoREMA - Zbornik radova, Zagreb: KoREMA, str. 39-43.

Wagner, I. (2. 7. 2019.) Leading cities for car-sharing worldwide by fleet size 2018, Statista Transportation \& Logistics (online). Dostupno na: https://www.statista.com/statistics/1022210/leading-cities-car-sharing-worldwide-fleetsize/\#statisticContainer (27. 10. 2020.) 


\title{
EMPIRICAL RESEARCH ON USERS' ATTITUDES ABOUT CARSHARING IN THE REPUBLIC OF CROATIA
}

\author{
Dora Naletina \\ PhD, Assistant Professor, Faculty of Economics and Business, J.F. Kennedy 6, 10000 Zagreb, Croatia; \\ e-mail:dvuletic@net.efzg.hr \\ Ivan Kovač \\ PhD, Associate Professor, Faculty of Economics and Business, J.F. Kennedy 6, 10000 Zagreb, Croatia; \\ e-mail: ivan.kovac@efzg.hr
}

\section{Dora Palić}

Mag. oec. e-mail: dora.palic4@gmail.com

\begin{abstract}
The urban population has been growing and this is the current issue many cities are facing, especially those not planned in the way as to provide for the commuting of continuously growing number of people. This leads to traffic congestions in urban areas, pollution, over-use of non-renewable energy resources and noise pollution vehicles create. The possible solution to this problem of mass transportation may be found in the form of carpooling i.e. the system of car-sharing based on the principle of sustainable development. In the last decades, buying and owning a car has become more affordable, this resulting in the development of road networks that have been overloading urban areas. However, due to the facts that parking has become an issue in these areas, and that costs of owning a personal car have been increasing, carpooling has been gaining on popularity throughout the world. In line with that, the purpose of this paper is to investigate users' attitudes on carpooling in the Republic of Croatia. The findings have shown that, although they are present on the Croatian market, a smaller number of the participants in the research use the services carpooling. The respondents who do use carpooling services state that the reasons for doing so are lower costs, avoiding the search for a parking spot and contributing to protecting the environment. The positive side to is that many respondents that have not yet used this service state they will be doing so in the future.
\end{abstract}

Key words: carsharing, mobility, urban transport 
